DOI: 10.15393/j9.art.2019.6522

УДК 821.161.1.09“1917/1992”

И. А. Спиридонова

Петрозаводский государственный университет (Петрозаводск, Российская Федерация)

verses@onego.ru

\title{
Мотивы ярости и зверя в рассказе А. Платонова «Одухотворенные люди»
}

Аннотация. В статье рассмотрены морфология и семантика мотивов ярости и зверя в рассказе А. Платонова «Одухотворенные люди» (1942). Мотивная организация произведения имеет отличия от советской эстетики героического и от традиции героического эпоса: в рассказе Платонова нарушена оппозиция «свое-чужое». В идейно-эстетическом каноне литературы Великой Отечественной войны закреплена антитеза мотивов народной ярости / врага-зверя (Л. Леонов, И. Эренбург и др.). В «Одухотворенных людях» семантически значима контаминация мотивов ярости, зверя и пустоты души, которые спроецированы на всю систему персонажей и ставят проблему опустошения / озверения человека в мире, ставшем войной. Данный мотивный комплекс имеет двухуровневую (текст-подтекст) структуру, переводит конфликт с внешнего (социально-политического) во внутренний (экзистенциальный) план, оппонирует названию произведения и выводит центральную тему «одухотворения» из героической риторики в метафизическую проблематику. Образное тождество «человек-животное», восходящее к мифу, в метафорическом развитии сюжета получает у Платонова ресемантизацию в контексте новозаветной традиции. Мотивы ярости и зверя, концентрируя трагедию человека на войне, находятся внутри сюжета, который открывает и завершает лейтмотив любви. Мотивы свободной любовной жертвы и благодарения жизни вынесены в финал духовной эволюции героев. Писатель показал духовную победу человека над злом войны - Агнца над Зверем. Эти смыслы жизни, выстраданные русским народом в веках истории, утвержденные в его православной духовности, наново открывают автор и его герои в смертельном противостоянии фашизму.

Ключевые слова: А. Платонов, мотив, образная параллель «человек-животное», подтекст, контекст, Л. Леонов, И. Эренбург, литература Великой Отечественной войны

Об авторе: Спиридонова Ирина Александровна - доктор филологических наук, профессор, кафедра классической филологии, русской литературы и журналистики, Петрозаводский государственный университет (пр. Ленина, 33, г. Петрозаводск, Республика Карелия, Российская Федерация, 185910) Дата поступления: 15.05.2019

Дата публикации: 18.10.2019

(с) И. А. Спиридонова, 2019 
Для цитирования: Спиридонова И. А. Мотивы ярости и зверя в рассказе А. Платонова «Одухотворенные люди» // Проблемы исторической поэтики. — 2019. — Т. 17. — № 4. - C. 301-325. DOI: 10.15393/j9.art.2019.6522

$\mathrm{P}$ ассказ А. Платонова «Одухотворенные люди» (1942) занимает особое место в литературе Великой Отечественной войны. В тяжелый, переломный период 1942-1943 гг. он был издан семь раз: в журналах «Краснофлотец» $(1942$, № 21) и «Знамя» (1942, № 11), в авторских сборниках «Броня» (1942) и «Рассказы о Родине» (1943), в антологии «Сталинское племя» (1943), отдельными брошюрами: «Одухотворенные люди» - в серии «Герои Отечественной войны» издательства «Молодая гвардия» (1942) и «Бессмертный подвиг моряков» в серии Военно-морского издательства НКВМФ СССР «Моряки - Герои Советского Союза» (1943). Этот рассказ стал народным чтением, одним из опорных произведений «литературы национального самоспасения» [Акимов: 81-82], что обусловило его выбор для более детального анализа мотивной структуры в этнопоэтическом аспекте. Мотив, по А. Н. Beceловскому, есть «образный ответ» на запросы времени [Веселовский: 448]. Развивая идеи Веселовского, В. Н. Захаров определяет этнологическую проблематику как один из центральных, научно актуальных вопросов исторической поэтики; в изучении национальной специфики русской литературы исследователь особое внимание уделяет православным аспектам этнопоэтики отечественной словесности [Захаров].

Реставрация национальной памяти - одна из главных заслуг русской литературы Великой Отечественной войны. Исторический, религиозный, бытовой, философский, художественный опыт, аккумулированные в национальной культуре, были необходимы человеку и народу, чтобы выстоять в трагические годы войны. Военные произведения Платонова ответили на этот духовный запрос. Национальная картина мира «прописана» в названиях его военных произведений: «Божье дерево (Дерево Родины)», «Одухотворенные люди», «Домашний очаг», «Взыскание погибших», «Девушка Роза», «Среди народа (Офицер и крестьянин)» и др. 
«Одухотворенные люди» посвящены героической обороне Севастополя в ноябре 1941 г., подвигу моряков, которые ценой жизни остановили танковые атаки фашистов на рубеже Дуванкойского шоссе. Сохраняя документальную основу, Платонов пишет рассказ, а не очерк. В журнале «Краснофлотец», где был напечатан первый сокращенный вариант произведения под названием «Слава», его сопровождает редакционное примечание: «Подвиг пяти моряков, о котором рассказывает А. Платонов, вдохновил уже многих писателей и поэтов. Эти произведения несхожи в деталя $x$, но во всех них авторы с наибольшей силой стараются воспроизвести герочческое событие и его высокий патриотический смысл» (курсив здесь и далее в цитатах мой. - И. С.) $)^{1}$.

«Несхожесть в деталях» в представлении героического события и его патриотического содержания прослеживается у Платонова на всех уровнях художественного текста, о чем сигнализирует сложная мотивная структура, в которой нарушена оппозиция «свое-чужое», что ведет к реорганизации не только героической модели советской литературы, но и фольклорной традиции героического эпоса. Назначением литературы огненных лет писатель считал не только «службу вечной славы», но и «службу вечной памяти - всех мертвых и всех живых»². Жанровую специфику «Одухотворенных людей» сам Платонов обозначил в письме к жене с фронта как «реквием в прозе» ${ }^{3}$.

Андрей Платонов разделил героико-патриотический пафос Великой Отечественной, но он также сознавал, что в одном историческом событии трагически сошлись две войны: «священная война» спасения Родины и война, которая стала «постоянным явлением» цивилизации и глубоко проникла в души людей, - «вечная война» ${ }^{4}$. Анализу двух мотивов, которые формируют в «Одухотворенных людях» трагический подтекст героического сюжета, и посвящена данная статья.

Мотивы ярости и зверя в платоновском сюжете выступают единым семантическим блоком, в кульминационной точке схождения фиксируя преображение человека в яростного зверя в смертельном бою. Образное тождество человека и животного исконно в мировой культуре, оно играет важную роль 
в мифах разных народов, в том числе в русской мифологии, хранит память о разных стадиальных отношениях человека и природы, о драме обустройства человека в цивилизации, о поиске человеком своего истинного человеческого содержания. В художественном произведении «функцию конкретизации (универсального. - И. С.) образа несут метафоры. <...> Образ оформляется при помощи отдельных, совершенно различных, конкретно применяемых метафор; они, таким образом, семантически тождественны, но всегда морфологически различны» [Фрейденберг: 51]. Опираясь на этот базовый принцип «Поэтики сюжета и жанра» О. М. Фрейденберг, проследим морфологию и семантику мотивов ярости и зверя в художественной структуре рассказа «Одухотворенные люди».

В «Одухотворенных людях» мотив ярости присутствует уже в первом «батальном» предложении:

«А он (Красносельский. - И. С.) бежал сейчас по полю сражения вперед, лицо его было покрыто кровью и потом, он бежал, задыхаясь от смертной истомы, и кричал от ярости» ${ }^{5}$.

Кто «он», повествователь пояснит позже - персонажу, открывающему сюжет «смертельного боя», придано семантическое расширение. Далее мотив ярости объемлет разных героев и разные эпизоды трехдневного сражения русских моряков за Севастополь от рукопашного боя до битвы «живых душ» с железными танками врага, аккумулируя разные смыслы: «Он (Красносельский. - И. С.) с криком ярости, изгоняющим страх и содрогание тела, ворвался в окоп <...> и сразил врага прикладом в лоб» (75); «...маленькие толстые тела мин с воем неслись над телами людей и рвались на куски, словно от собственной внутренней ярости» (78); «Он (комиссар Поликарпов. - И. С.) поднял над головой, как знамя и как меч, свою отбитую руку, сочащуюся последней кровью жизни, и воскликнул в яростной и удовлетворенной радости своего сердца, погибающего за родивший его народ: “Вперед! За Родину, за вас!” (79); «...воевал он (Красносельский. - И. С.) с яростью и ровным упорством...» (88); «Пулемет Цибулько работал яростно и полезно, как сердце и разум его хозяина» (95); «Но второй танк (врага. И. С.) с отважной яростью влетел на шоссейную насыпь, наехав почти в упор на подразделение Фильченко» (103); «Одинцов дрожал от горя и ярости» (106); «И тогда в своей свободной 
силе и в яростном восторге дрогнуло сердце Николая Фильченко» (107).

Ярость - состояние вдохновения и ожесточения боя. Ярость моряков-краснофлотцев, защищающих Севастополь, в платоновском повествовании мотивирована жизненной необходимостью смертельного ответа врагу в Отечественной войне.

В первый день войны В. И. Лебедевым-Кумачом и А. В. Александровым была написана «Священная война»: ярость благородная стала лейтмотивом патриотического гимна народа в Великой Отечественной войне. «Смерть немецким оккупантам!» - этим призывом открывались все советские периодические издания, он звучал по радио и на митингах, его повторяли про себя. Литература военных лет работала на вооружение "рассвирепевшей», по определению А. Толстого, совести нации: «Возмездия!» А. Толстого, «Наука ненависти» М. Шолохова, «Убей его» К. Симонова, «Ярость. Репортаж с Харьковского процесса» Л. Леонова, «Слово ненависти» А. Твардовского, «Убей!» И. Эренбурга. Эти произведения нельзя изъять из трагического контекста времени: защита родной земли, жизни близких, будущего нации требовала реализации любви к Родине в ярости-ненависти к агрессору, патриотического долга - в смерти врага.

Лексемы ярость (благородная) и ненависть (священная), отредактированные эпитетами, стали синонимами в чрезвычайных обстоятельствах войны с фашистским агрессором, однако имеют разную культурную семантику и образный потенциал. Значение ненависти замкнуто в поле отрицательных человеческих эмоций: это «чувство сильнейшей вражды, неприязни» ${ }^{6}$, которое отрицает (уничтожает) самый образ объекта ненависти (ненавижу = не вижу). Ярость полисемантична, означает максимальную интенсивность состояния / действия: лексема хранит первобытную память «о яри как высшем проявлении производительных сил»; корень яр- (*jar) и его производные характеризуют в славянской и русской мифологии богов, природные стихии, флору, фауну, человека 7 . Как эмоциональное состояние человека ярость имеет негативное, «низкое» значение («сильный гнев», «бешенство»), но сохраняет и положительные коннотации («крайняя увлеченность, 
настойчивость, напористость $<\ldots>$ в осуществлении какоголибо действия» $\left.{ }^{8}\right)$.

В «Одухотворенных людях» отсутствует лексема ненависть ${ }^{9}$, в то время как любовь и ее дериваты использованы многократно: «Она (девушка - И. С.) плакала от чувства любви, от памяти по человеку, который был сейчас на войне...» (74); «...это она (мать - И. С.), полюбив своего сына, вместе с жизнью подарила ему тайное свойство хранить себя от смерти, действующее быстрее помышления, потому что она любила его и готовила его в своем чреве для вечной жизни, так велика была ее любовь» (74-75); «...его хранила любовь к своей невесте» (88); «И от него, быть может, начнется освобождение мирного человечества, чувство к которому в нем рождено любовью матери...» (107) и т. д.

Мотив любви у Платонова вступает в сложный, напряженный сюжетный диалог с мотивом ярости. Последний трижды персонально закреплен в повествовании за Иваном Красносельским, русским богатырем, о котором сказано:

«...он бы должен свирепствовать в жизни, но он был кроток и терпелив; одна нежная, невидимая сила управляла этим могучим существом и регулировала его поведение с благородной точностью» (88).

«Невидимая сила», управляющая им с «благородной точностью», - любовь к невесте. На войне показано трагическое раздвоение героя, в котором живут два взаимоисключающих, насильственно объединенных войной чувства:

«Он жил <...> в счастье своей любви <...> и воевал он с яростью и ровным упорством, видимо, потому, что хотел своим воинским подвигом приблизить время победы, чтобы начать затем совершение другого подвига - любви и мирной жизни» (88).

Центральным для темы беспощадности войны, у которой один закон «убей!» и для агрессора, и для защитника Родины, является в «Одухотворенных людях» эпизод, где получает лексическое оформление мотив зверя, и характеризует он у Платонова защитников Отечества. Анималистическая тема занимает важное место в платоновском творчестве, присутствует она и в данном рассказе, что позволяет говорить именно о мотиве 
зверя при однократном прямом лексическом обозначении его в повествовании. Свою роль в сюжетной реализации мотива зверя у Платонова играет мотив ярости с его мифопоэтической памятью родства животного и человека. Ниже приведем фрагмент текста, где сходятся два мотива, курсивом выделив художественные элементы, которые «свидетельствуют» о превращении человека в зверя, о неизбежной и необходимой для победы переплавке патриотизма в смертельную беспощадность к врагу и к себе:

«Одинцов и Паршин часто дышали, лица их покрылись гарью и земляной грязью, но в глазах их был свет силы и неутоленное ожесточение боем. <...>

Паршин в волнении, не зная, что ему делать и как остановить себя, погладил почерневшей ладонью земляную стену блиндажа:

- Давай их крошить, командир! А то я один пойду!.. Я никогда не любил так народ, как сейчас, потому что они его убивают. До чего они нас довели - я зверем стал!.. Сыпь мне в рот порох из патронов - я пузом их взорву!

- Ты сам знаешь, патронов больше нет, — произнес Фильченко и снял с себя винтовку.

Одинцов дрожал от горя и ярости.

- Пошли на смерть! Лучше ее теперь нет жизни! - пробормотал он тихо» (105-106).

В развитии сюжета «Одухотворенных людей» мотив зверя существует в блоке лейтмотива ярости как вариант и одновременно кульминация. В рассмотренном эпизоде мотив зверя становится смысловым центром и включает в свое семантическое поле ярость как вариант. Именно мотив человека-зверя придает рассмотренной сцене статус сюжетного события. Сюжетное событие, в отличие от мотива, «должно обладать как раз противоположным признаком - единичности; повторяемость сюжетного события лишает его качества событийности» [Дымарский: 149]. На лингвопоэтическом уровне событийность актуализирована глагольной формой прошедшего времени совершенного вида («До чего они нас довели - я зверем стал!»), что придает сказанному значение состоявшегося, завершенного события. Это личное признание Юрия Паршина, потрясенного бездной ярости зверя, которую он в себе открыл; но то же самое чувствуют и сознают и другие 
краснофлотцы. В «горе и ярости» Одинцов ответит товарищу: «Пошли на смерть! Лучше ее теперь нет жизни!» (106).

Мотивы любви и ярости реализованы в анализируемом эпизоде как повтор неповторяемого. Патриотизм, любовь к ближнему, чувство товарищества заявлены в рассказе главными побудителями героической борьбы моряков. Но, лишь прожив беспощадную ярость боя, они открывают в себе новую по качеству и силе способность любить. Это первое переплетение мотивов. Мотив качественно новой высшей любви сопряжен с мотивом качественно новой высшей ярости -ярости зверя, - которую обнаруживают в себе герои и которая трагически обеспечивает исполнение патриотического долга: «Они смотрели на танки, идущие на них, и желали, чтобы машины шли скорее: лишь смертная битва могла их теперь удовлетворить» (102). Это второе переплетение мотивов, которое уже не позволяет «развязать» трагический узел противоречий. М. Шелер, рассматривая феномен трагического в его бытийной данности, отмечает, что антагонистические начала в трагическом событии явлены как «определенное свойство мира, данное в самом событии <...> в мгновенно связанной данности. <...> Даже более того: это может реализоваться в одном и том же качестве, в одной и той же силе, в одной и той же способности или возможности» [Шелер: 304306]. Любовь и ярость у Платонова - ядро художественной формулы трагического самораздвоения человека на войне.

При эстетическом оформлении трагического в линейной длительности художественного текста важна композиционная последовательность смены-сцепки мотивов. Русские моряки, не имея возможности в настоящем, которое есть звериная ярость боя, претворить выстраданное ими знание истинной ценности любви, свободно входят в смерть, в ней осуществляя свою тождественность Жизни, восстанавливая утраченную гармонию бытия («Пошли на смерть! Лучше ее теперь нет жизни!»).

Положительный, в ряде случаев, оправдательный смысл, который получает в «Одухотворенных людях» лексема ярость при описании психологического состояния защитников Севастополя, сохраняется писателем и в единожды присутствующей в тексте рассказа характеристике одержимости боем фашистов: 
«Но второй танк (врага. - И. С.) с отважной яростью влетел на шоссейную насыпь, наехав почти в упор на подразделение Фильченко» (103). Нарушение границы свое-чужое обнаруживается у Платонова и в развитии мотива зверя. Мотив зверя лексически оформлен и получает кульминацию в сюжете при характеристике защитников Отечества, при этом включает в себя зоологические характеристики врага («гады», «волосяной червь», «пустые шкурки от человека»). Английский переводчик и исследователь творчества Платонова Р. Чандлер отмечает как устойчивую и семантически важную конструкцию платоновского текста принцип конъюнкции: «Он использует удивительный предлог; создает эмоциональное предложение, написав $\boldsymbol{u}$, где мы ожидаем но...». «Сбои», «путаница» в мотивной структуре «Одухотворенных людей» сигнализируют об исторической трагедии воюющего человека по ту и эту сторону смертельного противоборства.

Для пояснения специфики мотивной структуры у А. Платонова обратимся к литературе огненных лет. Л. Леонов, писатель одного с Платоновым поколения, активно выступал в годы Великой Отечественной войны в жанре художественно-публицистического очерка. О военных произведениях писателя О. Михайлов пишет: «Перед нами та же проза Леонова, с ее уплотненным, на пределе возможностей языка словом, с ее многозначностью и внутренним свечением» [Михайлов: 598].

Мотивы ярости и зверя - сквозные в творчестве Леонова 1941-1945 гг. В очерке «Наша Москва» (1941) дан метафорический образ «Москвы - громадной летописи», хранительницы национального и мирового культурно-исторического опыта. Рассказ о Москве ноября 1941 г. пронизан патриотическим пафосом, но лексема «любовь» в тексте отсутствует - ее замещает «ярость»: «Слишком много воспоминаний у нас о Москве, и потому родина полна решимости защищать этот древний мировой город. <...> Всею индустриальной громадой порабощенной Европы напирает на нас враг, но никогда Гитлер не увидит коленопреклоненной нашу Москву. С каждым днем крепнет ярость нашего народа» ${ }^{11}$. В очерке «Размышление у Киева»: «Она (победа. - И. С.) в десятке признаков и прежде всего в нашей неукротимоц̆, все возрастающей ярости» ${ }^{12}$. 
Кульминация темы национального гнева - очерк 1943 г. «Ярость. Репортаж с Харьковского процесса», где ярость идет вслед и в одном блоке с мотивом мщения. «Пусть скорбь о безвинно убитых женщинах и детях наших будет потом, когда свершится мщение. А пока лишь сжимаются кулаки, и уже недостаточным оказывается бедный инструмент человеческой речи. Советские пушки и автоматы полнее и убедительнее выразят наше немое презрение и ярость...» ${ }^{13}$.

Спутник-антагонист мотива народной ярости в военных выступлениях Леонова - мотив врага-зверя (он является одним из ведущих в разработке темы врага у И. Эренбурга, М. Шолохова, А. Толстого, Б. Полевого и др.). В очерке «Наша Москва» мотив врага-зверя введен в повествование вслед мотиву народной ярости. Народную борьбу с захватчиками автор художественно воссоздает как борьбу с опасным «лесным зверем», опираясь на авторитет фольклорной традиции. Устойчивая антитеза мотивов ярости (защитников отечества) / зверя (врага) характерна для сюжетно-композиционной организации многих военных произведений Леонова. Во всех случаях мотивы ярости и зверя идеологически разведены: первый представляет в сюжете тему сражающегося за свободу народа, его любовь к родине, воплотившуюся в ненависть к врагу, второй - вероломного агрессора, его преступления против русского народа и человечества.

У Леонова есть прецеденты, когда мотив народной ярости включает в себя анималистические образы, но эти редкие включения лишь подтверждают общее правило. Мотив благородной ярости сражающегося за свободу народа диктует выбор образов животных, закрепленных в мировой и национальной культурной традиции как «благородных». В очерке «Поступь гнева»: «Что же сказать вам, освободители Харькова? Дрались, как львы? Мало! Как орль когтили вы вражескую нечисть на поле боя? Мало!..» ${ }^{14}$. Даже сравнения с этими царственными животными оказываются недостаточными для характеристики ярости воинов-освободителей. При этом выстраиваются анималистические оппозиции, в которых высокое, благородное начало противостоит низкому, бесчестному. Так, «орлиной» и «львиной» ярости освободителей Харькова противостоит 
смертельно раненный, но еще сильный и опасный враг-«волк»15. Животные образы, входящие в состав мотивов народной ярости и врага-зверя, как и в фольклорной традиции, этико-эстетически закреплены за каждой из противоборствующих сторон и не подлежат переадресовке. Фашизм - смертельная угроза человечеству, цивилизации и культуре. Именно из этой идеи вырастал разоблачительный образ-мотив врага-зверя. Тему врага-нелюдя у Леонова продолжают и развивают фантастические образы: «гомункулы» («Документы, сделанные кистью»), «оборотни», «упыри» («Имя радости»), «вурдалаки», «черти» («Немцы в Москве»), «дьяволы» («Ярость. Репортаж с Харьковского процесса»), - свидетельствующие о враждебности фашизма всему живому, его несовместимости с жизнью.

Звероподобные, хтонические образы врага даны в военной новеллистике И. Эренбурга («Василиск», «Хуже зверей», «Волк в чепчике», «Живые тени», «Черные души» и др.). В 1942 г. рассказы, разоблачающие бесчеловечную сущность фашизма, выйдут отдельным сборником под общим названием «Василиск». Поясняя читателю название, И. Эренбург писал:

«В древности люди считали, что существует мифический зверь василиск. По описанию Плиния, василиск - ужасен. Когда он глядит на траву, трава вянет. Когда он заползает в лес, умирают птицы. Глаза василиска несут смерть. Но Плиний говорит, что есть средство против василиска: подвести его к зеркалу. Гад не может выдержать своего собственного вида и околевает.

Фашизм - это василиск. Он несет смерть. Он не хочет взглянуть на самого себя. Германия боится зеркала: она завешивает его балаганным тряпьем. Она предпочитает портреты чужих предков. Но мы ее загоним к зеркалу. Мы заставим немецких фашистов взглянуть на самих себя. Тогда они сдохнут, как василиск» ${ }^{16}$.

Таких ярких зооморфных образов-метафор врага нет в военной прозе Платонова. Анималистические характеристики врага, реальные и мифологические, в его военных рассказах встречаются редко, локализованы на периферии образной структуры, разнородны, свернуты в словосочетание или слово и даны, как правило, в речи персонажей: «комариная куча» («Рассказ о мертвом старике»), «гадюка», «хищник» («Дед-солдат»), «мошкара из болота» («Никодим Максимов»), «гончие псы» 
(«Три солдата»), «расчетливый муравьиный разум» («Пустодушие»), «зубы» и «челюсти дракона» («Челюсть дракона»), «сказочный многоглавый дракон» («Штурм лабиринта»). К тому же некоторые из поименованных в этом списке представителей фауны в других военных рассказах представлены Платоновым «героями жизни», которые ведут свою борьбу с фашистами и «работу по одушевлению мира». Так, в финале рассказа «Неодушевленный враг» главный герой размышляет:

«...у комара больше души и разума, чем в Рудольфе Вальце живом или мертвом, все равно; комар живет своим усилием и своей мыслью, сколь бы она ни была ничтожна у него, - у комара нет Гитлера, и он не позволяет ему быть. Я понимал, что и комар, и червь, и любая былинка - это более одухотворенные, полезные и добрые существа, чем только что существовавший живой Рудольф Вальц. Поэтому пусть эти существа пережуют, иссосут и раскрошат фашиста: они совершат работу одушевления мира своей кроткой жизнью»

А. Кулагина среди редких и разных зоологических представлений врага в военных рассказах Платонова прослеживает связь с фольклорными образами кровожадных, несущих смерть чудовищ (зме́я, дракона): от сравнений фашистов с «комариной кучей» и «мошкарой болотной» до образа «сказочного многоглавого дракона» [Кулагина: 102]. Важно отметить, что «сказочной» силы враг - «многоглавый дракон» - появляется в прозе Платонова только во второй половине войны, где речь идет о борьбе с фашизмом на немецкой территории: когда враг насмерть стоит за родной кров, свою землю. В рассказах 1941-1942 гг., несмотря на трагизм ситуации, анималистические представления врага у Платонова близки к фигуре фикции: «Какой он (немец. - И. С.) неприятель? Он фашист аль Гитлер! Неприятели раньше были, они были в крымскую, в турецкую кампанию... А это просто так себе, одна гадюка...»18.

В «Одухотворенных людях» А. Кулагина выделяет две анималистических характеристики врага: «гады» и «волосяной червь», - также отмечая в них «перекличку с былинным змеем» [Кулагина: 102]. «Последним гадом», по оценке краснофлотца Юрия Паршина, является Гитлер: «У него была еще мечта - самому, лично, в рукопашную сразиться с последним 
гадом на свете. Он полагал, что последний гад есть Гитлер...» (90). «Родовое» определение фашистов «гадами» прозвучит во время боя, когда политрук Фильченко даст команду: «Цибулько, пулемет по гадам...» (94). Вслед, в том же боевом эпизоде, образ врага-гада получит «реалистическое» обоснование: немцы, как рептилии, пытаются незаметно подползти к окопам русских моряков, прячась среди стада овец («...из овечьей тесноты привстал человек в серо-зеленой шинели и замахнулся на животных оружием» - 94).

В речи комиссара Лукьянова, обращенной к морякам, прозвучит сравнение врага с «волосяным червем»:

«Враг, как волосяной червь, лезет в глубь нашей земли, без которой нам нет жизни, - так рассечем врага здесь огнем! Будем драться, как спокон веку дрались русские - до последнего человека, а последний человек - до последней капли крови и до последнего дыхания!» (91-92).

Морфологически представляя литоту былинного змея, образ врага-червя семантически тождествен фольклорному чудовищу смертоносным содержанием: его проникновение в глубь земли, внутрь организма ${ }^{19}$ смертельно опасно, грозит разрушением глубинных, в том числе духовных основ русской жизни.

Зоологические уподобления врага в «Одухотворенных людях» включают еще один метафорический образ - «пустые шкурки от человека». По мнению Николая Фильченко, фашисты - это «только пустые шкурки от людей, набитые страхом перед тираном Гитлером!» (92). Сравнение фашистов с «волосяным червем» и метафора «пустые шкурки от людей» развивают образ врагагада; одновременно периферийная смысловая связка анималистических характеристик врага: волосяной / шкурки как варианты шерсти / шкуры - дает вторичную зоологическую метафору и позволяет рассматривать образ врага как человека-зверя.

Анималистический триптих врага в «Одухотворенных людях» имеет ряд ассоциативных связей с романом «Чевенгур», где мастер Захар Павлович размышляет о фатальном родстве человека с червем: «...он не мог превозмочь свою думу, что человек произошел из червя, червь же - это простая страшная трубка, у которой внутри ничего нет - одна пустая вонючая тьма» ${ }^{20}$. Пессимизм утраты «главного» смысла жизни и тождество человек-червь 
вызревают у Захара Павловича на почве национального исторического кризиса и «напоминают» о себе в «Одухотворенных людях» определениями врага как червя / гада, а также признаками пустоты («пустые шкурки от человека») и зловония (Красносельский «почувствовал чуждое зловоние и сразил врага прикладом» - 75).

В метафорическом развитии сюжета «Одухотворенных людей» проблема зверя охватывает обе противоборствующие стороны. Вернемся к эпизоду, когда на поле боя неожиданно появляется стадо овец:

«А тут еще набежали овцы, которые шли теперь прямо по головам краснофлотцев, дрожа и жалобно, по-детски, вскрикивая от страшной жизни среди человечества. <...>

- Цибулько! — крикнул Фильченко. - Дай нам дорогу вперед - через шоссе. Огонь по овцам!

Цибулько начал сечь овец <...>. Ближние передние овцы пали, а бежавиие за ними сообразили, где правда, и бросились по сторонам, в обход людей. <.. .> . .через немцев еще бежали напуганные, пылящие, сеющие горошины овцы, и немцы их рубили палашами, чтобы освободиться от этих чертей, которых они взяли себе в прикрытие.

Моряки сработали гранатами быстро; они смешали кровь и кости овец с кровью и костями врагов» (95).

Точка зрения на этом повествовательном отрезке закреплена за овцами, и правда, с природной точки зрения, оказывается внеположна истории - людям, человечеству.

Претекстовая память мотива зверя в творчестве Платонова 1920-1930-х гг. поясняет его функции и семантику в «Одухотворенных людях» и военной прозе в целом. «Зверь больше не воскреснет на земле», - утверждал Платонов в статье «Преображение» 1920 г., так как против него «вспыхнул со страшной разрушающей мощью <. . .> человек - великий творец» ${ }^{21}$. В статьях первых пореволюционных лет писатель высказывался с ультрарадикальных революционных позиций, отрицая прошлое, природное и историческое, и приветствуя утопическое будущее «Золотой век, сделанный из электричества» (1921).

Социально-политическая практика осуществления утопий в отечественной и мировой истории ХХ века приводит Платонова к горькому выводу о торжестве Зверя в современной 
цивилизации. Лейтмотив зверя - структурообразующий в повести «Котлован» (1929-1930). Расчеловечивание людей в нескончаемой гражданской войне, массовая мутация в социальное животное - одна из главных тем «Котлована». Ключевым персонажем в мире разрушенных границ является зверь-пролетарий Миша Медведев. Медведь-молотобоец - зооантропоморфный образ, в котором концептуально значима двуединая природа ${ }^{22}$. Социализация персонажа дана под знаком очеловечивания-озверения: превращение медведя в человека и «возвратная метаморфоза». Именно второе перевоплощение делает исключительного, фантастического по художественной природе героя «типичным» в системе персонажей. Медведь, по древним поверьям, - лесной брат человека. Тему подобия-тождества медведя и человека хранит первобытный ритуал медвежьей охоты, важная часть которого - снятие шкуры с убитого медведя, что символизирует «первый этап принятия медведя человеческим коллективом» [Иванов, Топоров: 128]. Обрастание героев «Котлована» шерстью - «надевание шкуры» ${ }^{23}$ - прочитывается как контрэволюционное следствие революционной истории.

Вслед «Котловану» эта тема прозвучит в антифашистском рассказе «Мусорный ветер» (1933). Его главный герой физик Лихтенберг свидетельствует о жизни нацистской Германии: «...я вижу происхождение животных из людей...»" . Происхождение животных из людей получает в рассказе сюжетную реализацию: собака оказывается «бывшим человеком»; о самом Лихтенберге в формуляре поступающего в концлагерь написано: «Новый возможный вид социального животного, обрастает волосяным покровом...» ${ }^{25}$. Анималистические метаморфозы персонажей раскрывают их человеческую трагедию, трагедию фашизма. Мотив зверя в «Мусорном ветре», как и в «Котловане», семантически дуален: «показывает» утрату социумом гуманистического начала и природу как последнее убежище человека в мире социального зла. Авторская семантизация мотива зверя в творчестве Платонова 1920-1930-х гг. поясняют его «противоречивое» содержание и роль в военной прозе.

В художественной структуре «Одухотворенных людей» анималистический ряд характеристик, сигнализирующий об опасности утраты человеком человечности: гад, волосяной 
червь, пустая шкурка от человека, зверь - предваряет образ человека с пустой душой. Молодой музыкант Даниил Одинцов в ночь перед боем мечтает о послевоенном времени, где «будет опять хлеб у всех, люди будут читать книги, будет музыка и тихие солнечные дни с облаками на небе, будут города и деревни, люди будут опять простыми и душа ux cmaнеm nолной» (84). В этой идиллической картине будущего есть тревожный знак опустошения души человека войной. Светлую грезу героя сменяет апокалиптическое видение: «И Одинцову представилась вдруг пустая душа в живом, движущемся человеке, - и этот человек сначала убивает всех живущих, а потом терзает насмерть самого себя, потому что ему нет смысла для сущзествования и он не понимает, что это такое, он пребывает в постоянном ожесточенном беспокойстве» $(84)^{26}$.

Антропозооморфный образно-мотивный комплекс в «Одухотворенных людях» - в его синтагматическом развитии и тем более парадигматической перспективе - многозначен и оппонирует названию произведения, выводит его из героической риторики в экзистенциальную проблематику. Где духовно погиб / опустошен человек - торжествует зверь.

В Откровении Иоанна Богослова сказано: «Зверь, которого ты видел, был, и нет его, и выйдет из бездны, и пойдет в погибель; и удивятся те из живущих на земле, имена которых не вписаны в книгу жизни от начала мира, видя, что зверь был, и нет его, и явится» (Откр. 17:8).

Из записных книжек Платонова 1942-1943 гг.: «Война может стать постоянным явлением: к<а>к род новой промышленности, вышедшей из двух причин - некоторого “свободного" избытка пр<оизводительных> сил и “опустошения душ".

Война, весьма возможно, превратится в долгое свойство челов<еческого> общества. <...> “Вечная война” как выход в другое историч<еское > состояние (фаш<изм>)» $(3 К, 237)$.

Душа - главная арена борьбы добра и зла в человеке. Образ души в художественном мире Платонова занимает одно из центральных мест: об этом говорят высокая частотность и многообразие метафор, развивающих данную тему [Михеев: 174-206]. В анализируемом рассказе исходная формула защитников Отечества - «одушевленные люди» ${ }^{27}$ В ходе 
последующей работы Платонов меняет в заголовке определение «одушевленные» на «одухотворенные».

Оппозиция наполненности-пустоты души (одухотворенности-неодушевленности) раскрывается у Платонова в контексте народной православной культуры. Неодушевленный (враг), пустодушные - это народные определения фашистов в военных рассказах Платонова, которые свидетельствуют не об отсутствии души, а об утрате врагом-агрессором ее истинного содержания, прежде всего - совести. В рассказе «Пустодушие» ребенок спрашивает у матери:

«- Мама, а какие фашисты?..

- Немцы, - сказала мать, - они пустодушные, сынок... <..> Они за свои грехи чужую кровь проливают, оттого и пустодушные.

- А мы какие? - узнавал ребенок.

- А мы - нет. Мы сами свою кровь проливаем и сами горе терпим. Мьи, когда грешны, свои грехи на другого не валим» ${ }^{28}$.

В «Одухотворенных людях»:

«Правда у нас, - размышлял краснофлотец над спящими товарищами. - Нам трудно, у нас болит душа. А фашисту легко, ему кажется жизнь смутной, не то есть она, не то она ему снится, поэтому он действует для одного своего удовольствия - то пьян напьется, то девушку покалечит, то в меня стрельнет» (84).

У русских воинов, защищающих Отечество, болит душа, потому что в ней жива совесть. Даже в ярости боя героям Платонова нужен оправдательный смысл, даже агрессора они убивают по трагической нужде защиты Отечества: «...чтобы он не убивал нас больше и не мучил наш народ страхом смерти» (75). «Оправдание» русского солдата в смертельном единоборстве с немцем, в необходимости убить врага присутствует в рассказе «Божье дерево (Дерево Родины)», написанном в августе 1941 г.:

«Теперь уже не смогу прощать тебя, - ответил Трофимов врагу. - Теперь уже не сумею... У меня мать есть, а ты ее сгонишь с земли» ${ }^{29}$.

Необходимость опереться на правду, прислушаться к совести в страшной работе войны по уничтожению врага постоянная забота «одухотворенных людей» Платонова. 
Принципиально важно, что мотивы пустоты души и зверя введены в повествование через слово и мысль героев - как саморефлексия. «Зрячее, или именуемое», по определению А. Ф. Лосева, нахождение «себя в себе же» играет первостепенную роль в самоидентификации личности: «Это - различающее нахождение себя и как иного себе и как себя самого» [Лосев: 66-67].

Даниил Одинцов думает перед боем:

«А этот бледный огонь врага на небе и вся фашистская сила это наш страшный сон, в нем многие помрут, не очнувшись, но человечество проснется...» (84).

Мысль героя имеет возвратную семантику - обращенность на себя, - актуализируя в подтексте тему онтологического зла. Из военного блокнота Платонова: «Зло въяве, наружи это только то, что у нас есть внутри. Это наши же извержения, чтобы мы исцелились» $(3 К, 219)$. В яростном ожесточении смертельного боя Юрий Паршин открывает в себе «зверя». Герои Платонова из тех, кто «очнулся» - прозрел в аду войны, - ведь осознание в себе зверя есть опорная точка в усилии возвращения человека к себе самому.

Защитники Севастополя в рассказе «Одухотворенные люди» проходят сложную эволюцию, открывая смысл жизни и смерти, в последнем бою мысленно произносят слова благодарения жизни за то, что они родились жить здесь и сейчас. Личная смерть солдата в бою с немецкими захватчиками становится последним, крайним средством не только защиты общенародной жизни, но и выявления ее истинного содержания. Комиссар Поликарпов погибает со словами, обращенными к бойцам: «За Родину, за вас!» (79). Умирая, он передает боевым товарищам заветные смыслы патриотизма и любви к ближнему. Бойцы вспоминают погибшего командира: «Такие люди долго не держатся на свете, а свет на них стоит вечно» (80); «- Комиссар говорил, что мы для него - всё, что мы для него родина. И он тоже родина для нас» (83). Краснофлотцы открывают для себя новое содержание жизни и смерти на войне - «защитить добрую правду русского народа» (84).

Духовная эволюция политрука Фильченко в эти три дня сражения за Севастополь - от жажды мщения врагам до 
радости дарения себя Родине, правде, народу. Готовясь к единоборству с фашистским танком, Николай Фильченко всматривается в родную, истерзанную войной землю, на которую наползает железная смерть:

«Жалкие живые былинки, росшие по откосу, погибшая овияа и чьи-то давно иссохшие кости равно вдавливались ребрами танковых гусениц в терпеливый прах земли» (107).

Натуралистически точная детализация «сокращающегося пространства» передает психологическую концентрацию человека в последний, решающий момент смертельного поединка. Одновременно эти физические знаки имеют метафизическое содержание, символически представляют мистериальную драму вечного единоборства жизни и смерти, в которую готовится вступить человек. В этот судьбоносный момент происходит открытие героем жизни как добровольной любовной жертвы:

«И тогда в своей свободной силе и в яростном восторге дрогнуло сердие Николая Фильченко. Перед ним, возле него было его счастье и его высшая жизнь, и он ее сейчас жадно и страстно переживет, припав к земле в слезах радости, потому что сама гнетущая смерть сейчас остановится на его теле и падет в немощи на землю по воле одного его сердца. <...> Он прицелился точно - так, чтобы граната, привязанная у его живота, пришлась посредине ширины ходового звена гусеницы, - и приник лицом к земле в последней любви и доверчивости» $(107)^{30}$.

Катарсисом трагического сюжета в художественном решении Платонова станет кроткий подвиг любви - победа Агнца над Зверем в душе человеческой: «Они будут вести брань с Агнцем, и Агнец победит их...» (Откр. 17:14). Герои Платонова, его «одухотворенные люди», утверждаются в вере, что сделать мир «святым и одушевленным» (85) может только любовь.

А. Киселев пишет об «одухотворении мира» как важнейшем принципе эстетики Платонова, восходящем и опирающемся на народную православную культуру: «Платонов в своих произведениях старается выявить Бога и сил небесных, действующих и в современном мире. Однако описания, выявляющие метафизическую реальность, строятся им так, что человек, близкий церкви, уже знакомые образы примет за реальные, а мало знающий 
православие - за сюрреалистическое описание, являющее вспомогательный момент в описанных событиях» [Киселев: 82].

Зооантропоморфный сюжет в «Одухотворенных людях» имеет двухуровневую (текст-подтекст) структуру, сложный мотивный комплекс переводит конфликт с внешнего (социально-политического) во внутренний (экзистенциальный) план. Образное тождество человек-животное, восходящее к мифу, в метафорическом развитии сюжета получает у Платонова ресемантизацию в контексте новозаветной традиции. Контаминация мотивов ярости, зверя и пустоты души, их сюжетная стяжка ставит проблему опустошения / озверения человека в мире, ставшем войной, сигнализирует об исторической трагедии человека в полном объеме индивидуальном, национальном, общечеловеческом. При этом трагические мотивы не разрушают, а усиливают героический пафос «Одухотворенных людей». Зооантропоморфный мотивный комплекс, концентрируя трагедию человека на войне, находится внутри сюжета, который открывает и завершает лейтмотив любви. Мотивы свободной любовной жертвы и благодарения жизни вынесены в финал духовной эволюции героев. Высокий патриотический смысл Отечественной войны развернут у Платонова из «злободневности» в вертикаль совести - нет другого выхода из «вечной войны». Писатель показал духовную победу человека над злом войны - Агнца над Зверем. Эти смыслы жизни, выстраданные русским народом в веках истории, утвержденные в его православной духовности, наново открывают автор и его герои в смертельном противостоянии фашизму.

\section{Примечания}

1 [От редакции] // Краснофлотец. 1942. № 21. С. 2.

2 Платонов А. Записные книжки. Материалы к биографии. М., 2000. С. 280. Далее ссылки на это издание приводятся в тексте статьи с использованием сокращения ЗК и указанием страницы в круглых скобках.

3 «...Живя главной жизнью»: А. Платонов в письмах к жене, документах и очерках // Волга. 1975. № 9. С. 174.

4 «"Вечная война" как выход в другое историч<еское> состояние (фаш<изм>)» (3К, 237).

5 Платонов А. П. Одухотворенные люди // Платонов А. П. Смерти нет! Рассказы и публицистика 1941-1945 гг. / сост., подгот. текста, коммент. Н. В. Корниенко. М.: Время, 2010. (Собрание). С. 74. Далее ссылки на это издание приводятся в тексте статьи с указанием страницы в круглых скобках. 
6 Словарь русского языка: в 4 т. 3-е изд. М.: Русский язык, 1988. Т. 2. С. 456.

7 Мифологический словарь. М.: Сов. энциклопедия, 1991. С. 650-651.

8 Словарь русского языка. Т. 4. С. 785.

9 В ходе редакторской правки «ненависть» была вписана в платоновский рассказ при последней прижизненной его публикации в сборнике «Рассказы о Родине»: Фильченко погибает «с последним вздохом любви и ненависти» (Платонов А. Одухотворенные люди // Платонов А. Рассказы о Родине. М., 1943. С. 37). В машинописи Платонова: «...и приник лицом к земле в последней любви и доверчивости» (Платонов А. Вечная слава [машинопись] // РГАЛИ. Ф. 2124. Оп. 1. Ед. хр. 38. Л. 63). Подробнее о судьбе платоновского текста см.: [Спиридонова].

10 Перевод с англ. яз. мой. - И. С. В оригинале: «Не uses a surprising preposition; he drains a sentence of emotion by writing and where we expect but...» [Chandler: 21].

11 Леонов Л. Собрание сочинений: в 10 т. М.: Худож. лит., 1984. Т. 10: Публицистика; Фрагменты из романа. С. 84.

12 Там же. С. 129.

13 Там же. С. 134.

14 Там же. С. 127. В других произведениях Леонова находим анималистические метафоры, вырастающие из этих же сравнений: «орлиная русская слава» («Неизвестному американскому другу. Письмо первое»); «львиный гнев богатырского сердца» («Слава России»).

15 Там же. С. 128. Активно используя образ волка для разоблачения гитлеризма вплоть до последних выступлений в печати победной весной 1945 г., Леонов в одном из них принес зверю извинения. В очерке «Немцы в Москве» (1944) автор, вглядываясь в пленных немецких генералов, замечает: «Даже не смирение волка, у которого перебит шейный позвонок, читалось в этих щеголеватых фигурах, ибо есть и у волка своя смертная гордая стать: тупое равнодушие прочла Москва во всем облике всемирных бесстыдников» (Там же. С. 158).

16 Эренбург И. Василиск. Куйбышев: ОГИЗ, 1942. С. 5.

17 Платонов А. Неодушевленный враг // Платонов А. Одухотворенные люди. Рассказы о войне. М.: Правда, 1986. С. 284.

18 Платонов А. Дед-солдат // Пионер. 1941. № 10. С. 21.

19 В научной классификации многочисленных животных этого типа (черви) не встречается название «волосяной червь», однако названия отрядов класса круглых червей, среди которых много паразитов, имеют «волосяной потенциал» - это отряды 1) колючеголовых и 2) нитчатых червей, или нематод, с которыми соединяются также щетинко-челюстные черви. Среди самых опасных для человека паразитов этого класса червей числится мускульная, или спиральная, трихина (Trichina spiralis), один из видов которой получил название человеческий власоглав (Trichocephalus dispar) см.: [Брэм].

20 Платонов А. Чевенгур. М.: Высшая школа, 1991. С. 34. 
21 Платонов А. Преображение // Платонов А. Сочинения. М.: ИМЛИ PAH, 2004. Т. 1. Кн. 2. С. 19.

22 Вводная портретная характеристика: «Утерев затем свое утомленнопролетарское лицо, медведь плюнул в лапу и снова приступил к труду молотобойца» (Платонов А. Котлован: Текст, материалы творческой истории / ИРЛИ РАН (Пушкинский Дом). СПб.: Наука, 2000. С. 89). См. также сюжетную схему персонажа в рабочих записях:

[Медведь - кузнец в колхозе, молотобоец, раскулачивает.] (3К, 35).

23 Описание умирающей матери Насти: «...ноги были покрыты густым пухом, почти шерстью, выросшей от болезней и бесприютности...» (Платонов А. Котлован: Текст, материалы творческой истории... С. 56). Органико-зооморфная детализация портрета пролетария Чиклина: «...имел маленькую, каменистую голову, густо обросшую волосами, потому что всю жизнь либо бил балдой, либо рыл лопатой, а думать не успевал...» (Там же. С. 42). Мужик Елисей - «уже обрастающ[ий] защитной шерстью» (Там же. С. 61) и т. д.

24 Платонов А. П. Мусорный ветер // Платонов А. П. Счастливая Москва: Роман, повесть, рассказы / сост., подгот. текста, коммент. Н. В. Корниенко. М.: Время, 2011. 2-е изд., стереотип. (Собрание). С. 278.

25 Там же. С. 281.

26 Вслед авторскому варианту текста, хранящемуся в РГАЛИ, этот фрагмент был полностью опубликован в «Знамени» (1942. № 11. С. 121).

27 Платонов А. Одушевленные люди. Рассказ о небольшом сражении под Севастополем // Знамя. 1942. № 11. С. 115-136.

28 Платонов А. Пустодушие // Платонов А. Одухотворенные люди. Рассказы о войне. С. 214.

29 Платонов А. Дерево Родины // Платонов А. Одухотворенные люди. Рассказы о войне. С. 88.

30 Платонов А. Вечная слава [машинопись] // РГАЛИ. Ф. 2124. Оп. 1. Ед. хр. 38. Л. 63. Авторская итоговая формула эволюции героя будет сохранена при публикации произведения в «Знамени» (1942), в отдельных изданиях: «Одухотворенные люди» (1942) и «Бессмертный подвиг моряков» (1943), в антологии «Сталинское племя» (1943), в сборнике «Броня» (1943). И только в сборнике «Рассказы о Родине» (подписан к печати 3 октября 1943 г.) последнее предложение будет отредактировано: «...с последним вздохом любви и ненависти». Соответственно будет отредактирован и духовный финал героя. Эта последняя прижизненная публикация рассказа «Одухотворенные люди» с многочисленными нарушениями воли автора станет основным источником при переизданиях произведения в послевоенные десятилетия.

\section{Список литературы}

1. Акимов В. М. От Блока до Солженицына. Судьбы русской литературы XX века (после 1917 года): новый конспект-путеводитель. - СПб.: Изд-во Академии культуры, 1994. - 164 с. 
2. Брэм А. Э. Жизнь животных: в 3 т. - М.: Терра, 1992. - Т. 3: Пресмыкающиеся. Земноводные. Рыбы. Беспозвоночные. - 1370 с.

3. Веселовский А. Н. Историческая поэтика. - Л.: Худож. лит., 1940. - 649 с.

4. Дымарский М. Я. Еще раз о понятии сюжетного // Алфавит: Строение повествовательного текста. Синтагматика. Парадигматика. - Смоленск: Изд-во СГПУ, 2004. - С. 139-150.

5. Захаров В.Н. Проблемы исторической поэтики. Этнологические аспекты. - М.: Индрик, 2012. - 264 с.

6. Иванов В. В., Топоров В. Н. Медведь // Мифы народов мира. Энциклопедия: в 2 т. - 2-е изд. - М.: Советская энциклопедия, 1992. - Т. 2. - С. 128-130.

7. Киселев А. Одухотворение мира // Молодой коммунист. — 1989. — № 11. — C. 78-85.

8. Кулагина А. Образ русского ратника в фольклоре и в военной прозе А. Платонова // «Страна философов» Андрея Платонова: проблемы творчества. - М.: ИМЛИ РАН, 2003. - Вып. 5. - С. 101-107.

9. Лосев А. Ф. Философия имени // Лосев А. Ф. Из ранних произведений. М.: Правда, 1990. - С. 11-194.

10. Михайлов О. Примечания // Леонов Л. Собр. соч.: в 10 т. - М.: Худож. лит., 1984. - Т. 10: Публицистика. Фрагменты из романа. - С. 595-622.

11. Михеев М. Ю. В мир Платонова через его язык. Предположения, факты, истолкования, догадки. - М.: Изд-во Московского ун-та, 2003. - 408 с.

12. Спиридонова И. А. Рассказ Платонова «Одухотворенные люди»: текст и контекст // Творчество Андрея Платонова: исследования и материалы. СПб.: Наука, 2008. - Кн. 4. - С. 217-233.

13. Фрейденберг О. М. Поэтика сюжета и жанра. - М.: Лабиринт, 1997. - 448 с.

14. Шелер М. О феномене трагического // Проблемы онтологии в современной буржуазной философии. - Рига, 1988. - С. 298-317.

15. Chandler Robert. Translaiting Soul // Platonov Andrey. Soul. - London: The Harvill Press, 2003. - Pp. 19-26.

Irina A. Spiridonova

Petrozavodsk State University

(Petrozavodsk, Russian Federation)

verses@onego.ru

\section{The Motifs of Rage and Beast in Andrey Platonov's Story “Odukhotvorennye lyudi” (“Inspired People”)}

Abstract. The article discusses the morphology and semantics of the rage and beast motifs in the story by A. Platonov "Odukhotvorennye lyudi" (1942). The motivic organization of the work significantly differs from the Soviet aesthetics of the heroic and the traditions of the heroic epos: in the Platonov's story the opposition Us vs. Them is disrupted. In the ideological and aesthetic canon of the literature on the Great Patriotic War, the antithesis of the motifs of the people's rage and the enemy-beast is enshrined (L. Leonov, I. Ehrenburg et al.). The "Odukhotvorennye lyudi" puts a semantic emphasis on the contamination of the 
motifs of the rage, the beast and the void in the human soul. This motivic triad determines the entire system of characters and poses the problem of devastation / bestiality of a person in a world, which has turned into a bloodbath. This complex of motifs creates a two-level (text-subtext) structure and transfers the conflict from the external (socio-political) into the internal (existential) plan, thus, opposes the title of the work and deduces the central theme of inspiration from heroic rhetoric to metaphysical perspective. The figurative parallel Human $v s$. Animal that goes back to the myth, in the metaphorical development of the Platonov's plot receives re-semantization in the context of the New Testament tradition. The motifs of Rage and Beast, concentrating the tragedy of man in the war, remain within the plot, which opens and completes the leitmotif of Love. The free love sacrifice and thanksgiving of life motifs are put in the finale of the spiritual evolution of the characters. The writer showed the spiritual victory of man over the evil of war - the Lamb over the Beast. These meanings of life, obtained by the Russian people through the centuries of suffering, affirmed in their Orthodox spirituality, are discovered by the author and his characters anew in the deadly opposition to fascism.

Keywords: A. Platonov, motif, figurative parallel Human vs. Animal, subtext, context, L. Leonov, I. Ehrenburg, literature on the Great Patriotic War

About the author: Spiridonova Irina A. - Doctor of Philology, Professor, The Department of Classical Philology, Russian Literature and Journalism, Petrozavodsk State University (pr. Lenina 33, Petrozavodsk, Republic of Karelia, 185910, Russian Federation)

Received: May 15, 2019

Date of publication: October 18, 2019

For citation: Spiridonova I. A. The Motifs of Rage and Beast in Andrey Platonov's Story "Odukhotvorennye lyudi" ("Inspired People"). In: Problemy istoricheskoy poetiki [The Problems of Historical Poetics], 2019, vol. 17, no. 4. pp. 301-325. DOI: 10.15393/j9.art.2019.6522 (In Russ.)

\section{References}

1. Akimov V. M. Ot Bloka do Solzhenitsyna. Sud'by russkoy literatury XX veka (posle 1917 goda): novyy konspekt-putevoditel' [From Block to Solzhenitsyn. The Destiny of Russian Literature of the 20th Century (After 1917): a New Abstract Guide]. St. Petersburg, Akademiya kul'tury Publ., 164 p. (In Russ.)

2. Brem A. E. Zhizn'zhivotnykh: $v 3$ tomakh [The Life of Animals: in 3 Vols]. Moscow, Terra Publ., 1992, vol. 3. 1370 p. (In Russ.)

3. Veselovskiy A. N. Istoricheskaya poetika [The Historical Poetics]. Leningrad, Khudozhestvennaya literatura Publ., 1940. 649 p. (In Russ.)

4. Dymarskiy M. Ya. Once More About the Concept of a Plot Event. In: Alfavit: Stroenie povestvovatel'nogo teksta. Sintagmatika. Paradigmatika [An Alphabet: the Structure of a Narrative Text. Syntagmatics. Paradigmatics]. Smolensk, Smolensk State Pedagogical University Publ., 2004, pp. 139-150. (In Russ.) 
5. Zakharov V. N. Problemy istoricheskoy poetiki. Etnologicheskie aspekty [The Problems of Historical Poetics. Ethnological Aspects]. Moscow, Indrik Publ., 2012. 264 p. (In Russ.)

6. Ivanov V. V., Toporov V. N. A Bear. In: Mify narodov mira. Entsiklopediya: v 2 tomakh [World Myths. Encyclopedia: in 2 Vols]. Moscow, Sovetskaya entsiklopediya Publ., 1992, vol. 2, pp. 128-130. (In Russ.)

7. Kiselev A. Spiritualization of the World. In: Molodoy kommunist, 1989, no. 11, pp. 78-85. (In Russ.)

8. Kulagina A. The Image of a Russian Warrior in Folklore and the Military Prose of A. Platonov. In: «Strana filosofov» Andreya Platonova: Problemy tvorchestva ["Country of Philosophers" by Andrei Platonov: The Problems of Creative Work]. Moscow, The Institute of World Literature of the Russian Academy of Sciences Publ., 2003, issue 5, pp. 101-107. (In Russ.)

9. Losev A. F. The Philosophy of a Name. In: Losev A. F. Iz rannikh proizvedeniy [Losev A. F. From His Early Works]. Moscow, Pravda Publ., 1990, pp. 11-194. (In Russ.)

10. Mikhaylov O. Notes. In: Leonov L. Sobranie sochineniy: $v 10$ tomakh [Leonov L. Collected Works: in 10 Vols]. Moscow, Khudozhestvennaya literatura Publ., 1984, vol. 10, pp. 595-622. (In Russ.)

11. Mikheev M. M. V mir Platonova cherez ego yazyk. Predpolozheniya, fakty, istolkovaniya, dogadki [Into the World of Platonov Through His Language. Assumptions, Facts, Interpretations, Speculations]. Moscow, Moscow State University Publ., 2003. 408 p. (In Russ.)

12.Spiridonova I. A. Platonov's Story "Inspired People": Text and Context. In: Tvorchestvo Andreya Platonova: issledovaniya i materialy [The Work of Andrey Platonov: Studies and Materials]. St. Petersburg, Nauka Publ., 2008, book 4, pp. 217-233. (In Russ.)

13. Freydenberg O. M. Poetika syuzheta i zhanra [The Poetics of Plot and Genre]. Moscow, Labirint Publ., 1997. 448 p. (In Russ.)

14. Sheler M. On the Phenomenon of the Tragic. In: Problemy ontologii v sovremennoy burzhuaznoy filosofii [The Problems of Ontology in Modern Bourgeois Philosophy]. Riga, 1988, pp. 298-317. (In Russ.)

15. Chandler Robert. Translaiting Soul. In: Platonov Andrey. Soul. London, The Harvill Press Publ., 2003, pp. 19-26. (In English) 